\title{
Antropologi Sastra: \\ Mata Rantai Terakhir Analisis Ekstrinsik
}

\section{Nyoman Kutha Ratna ${ }^{1}$}

\begin{abstract}
Abstrak
Dalam bidang sastra, dikenal dua model analisis ekstrinsik, yaitu psikologi sastra dan sosiologi sastra. Dengan adanya kekayaan sekaligus keragaman aspek-aspek kebudayaan dalam kehidupan manusia, maka kedua jenis interdisiplin dianggap belum cukup. Antropologi sastra dianggap sebagai model interdisiplin yang dapat mengantisipasi kekuranagn tersebut. Antropologi sastra jelas melibatkan dua bidang ilmu yaitu antropologi dan sastra. Keduanya pada dasarnya memiliki persamaan, sama-sama memanfaatkan cerita dalam bentuk pengalaman sehari-hari. Etnografi dengan novel, baik dalam proses pengumpulan data maupun proses penulisannya, menunjukkan ciri-ciri yang relatif sama. Dalam teori kontemporer kedua penulisan makin sulit dibedakan, karya sastra yang cenderung ilmiah, etnografi yang cenderung literer. Untuk mengantisipasi perkembangan antropologi sastra ke depan, maka salah satu cara yang dapat dilakukan adalah memasukkannya ke dalam kurikulum.
\end{abstract}

Kata kunci: antropologi sastra, interdisiplin, novel, etnografi.

\section{Pendahuluan}

Sama dengan antropologi budaya yang tidak bisa dipisahkan dengan antropologi sosial, demikian juga pembicaraan mengenai antropologi sastra tidak bisa dilepaskan dari antopologi linguistik, etnolinguistik menurut perkembangan kemudian. Artinya, hubungan timbal balik yang sudah terjadi sejak berabad-abad, antara penelitian mengenai suku-suku bangsa dengan bahasanya masing-masing, demikian juga sebaliknya, mewarnai perkembangan sastranya. Antropologi linguistik jelas memiliki tujuan tersendiri, yaitu analisis bahasa dengan mempertimbangkan aspek-aspek kebudayaannya. Tujuan

\footnotetext{
${ }^{1}$ Guru Besar pada Universitas Udayana
} 
penelitian dianggap berhasil apabila analisis kebudayaan, sebagai analisis antropologis dapat memberikan sumbangan terhadap analisis bahasanya.

Tujuan akhir suatu penelitian tertentu mungkin merupakan awal dari penelitian lain yang dengan sendirinya akan memberikan makna yang lain. Demikian juga antara penelitian bahasa dan sastra. Pada umumnya penelitian sastra dilakukan sesudah penelitian bahasanya. Seperti di atas, berbagai bentuk pengumpulan data mengenai masyarakat dilakukan melalui pencatatan bahasa. Di samping itu, secara teoretis, bahasa adalah alat, sebagai sistem model pertama, sehingga penelitian dalam bentuk apa saja, maka bahasa merupakan prioritas yang kemudian sesuai dengan tujuan diikuti dengan penelitian sastranya.

Penelitian yang dilakukan terhadap bahasa Bali, misalnya, baik secara langsung maupun tidak langsung akan melibatkan sastranya. Tuuk, Margaret Mead, Clifford, dan Hildred Geertz telah banyak mengungkapkan masalah suku bangsa, bahasa, dan dengan demikian sastra Bali. Sebagai seorang orientalis sekaligus akademis, Zoetmulder membicarakan sastra Jawa (Kalangwan: Sastra Jawa Kuno Selayang Pandang), Teeuw banyak membicarakan sastra Indonesia Modern (Sastra Indonesia Modern I dan II, Tergantung pada Kata, Membaca dan Menilai Sastra). Contoh-contoh seperti ini akan bertambah panjang dengan banyaknya kelompok orientalis yang mencoba menulis mengenai bangsa Indonesia, baik selama masa penjajahan, maupun sesudahnya.

\section{Pembahasan}

\subsection{Antropologi dan Sastra}

Persamaan yang paling jelas antara antropologi dan sastra telah tampak sejak awal perkembangan kedua disiplin. Pertama, secara historis antropologi mulai dengan catatan-catatan etnografis kelompok orientalis, di dalamnya baik secara langsung maupun tidak langsung termasuk bahasa dan sastra. Demikian juga sebaliknya, para peneliti bahasa dan sastra pada gilirannya juga memasukkan aspek-aspek etnografis dan antropologisnya. Korpus data kedua model penelitian jelas merupakan cerita dengan para tokoh, kejadian, tema, dan latar, bahkan juga gaya bercerita masing-masing. Oleh karena itu, kedua disiplin menganggap folklore sebagai wilayah penelitian masing-masing.

Kedua, kedua disiplin pada dasarnya menggunakan metode dan teori yang relatif sama seperti interpretasi dengan berbagai variannya. Bertitik tolak dari pendapat Langer, menurut Geertz (1973:3-30) kebudayaan, yaitu catatan- 
catatan etnografis itu sendiri pada dasarnya adalah tafsiran-tafsiran, sebagai tafsiran pertama, bahkan tafsiran kedua dari para etnografer yang pada dasarnya tidak jauh berbeda dengan sebuah novel dan bentuk-bentuk karya sastra yang lain. Menurut Geertz catatan asli hanya dimiliki oleh penduduk asli. Pada gilirannya catatan-catatan yang sudah ditafsirkan itulah yang harus ditafsirkan kembali. Analisis inilah yang akan menghasilkan pemahaman secara menyeluruh, sebagai deskripsi tebal. Secara teoretis kedua disiplin juga menunjukkan persamaan. Sejak diperkenalkannya teori strukturalisme awal abad ke-20 baik antropologi maupun sastra menggunakan teori tersebut, sehingga sulit dipisahkan antara strukturalisme Saussurean dengan LeviStraussian. Bahkan kedua tokoh diklaim sebagai pelopor teori-teori strukturaslisme.

Hubungan antara antropologi dengan sastra paling jelas apabila dikaitkan dengan etnografi dengan novel, karya sastra dengan ciri-ciri struktur naratif total. Secara praktis sulit membedakan antara novel dengan kisah perjalanan, perjalanan wisata, cerita mengenai suku-suku bangsa, baik ditulis dengan sengaja maupun tidak, baik dengan citra negatif maupun positif. Seorang wisatawan, ilmuwan, dan orientalis pada saat menceritakan kehidupan suku bangsa tertentu, di samping menampilkannya secara objektif sebagaimana dialaminya, baik secara sadar maupun tidak sadar menceritakan masalahmasalah subjektivitas. Mereka cenderung menambahkannya demikian rupa, mungkin sebagai akibat keheranannya terhadap peristiwa yang dialami, atau sebab-sebab lain dalam kaitannya dengan proses penulisan tersebut.

Benar, secara teoretis etnografi termasuk karya ilmiah, bukan fiksi. Tetapi apabila diperhatikan lebih jauh model penulisan secara keseluruhan hampir sama dengan penulisan novel. Sebagai sebuah cerita, seperti juga sejarah, maka konsekuensi logis yang ditimbulkan adalah usaha penulis untuk menyusun cerita menjadi masuk akal, logis. Cara-cara yang dilakukan, misalnya, menyusun kembali bahan-bahan kasar yang sudah diperoleh, menyeleksinya, sehingga membentuk alur, sebagai mekanisme pemplotan. Pada tahap terakhir ini karya etnografi persis sama dengan novel. Tulisan Geertz mengenai Mojokuto (Bachtiar, 1981: 521), misalnya, ternyata bahwa nama yang dimaksudkan disamarkan, fiksi.

Demikian juga dalam menentukan informan, demi menjaga kerahasiaan apabila ada masalah-masalah yang dianggap peka, maka dimungkinkan adanya kebebasan untuk menyembunyikan nama informan tersebut. Penelitian dengan 
melibatkan informan, maka informan yang dimaksudkan dapat disebutkan sebagai pencerita pertama, sedangkan peneliti merupakan pencerita kedua. Pada saat melakukan wawancara, baik melalui teknik purposif maupun bola salju, maka masalah yang sama diceritakan kembali oleh informan kedua, demikian seterusnya, sehingga terjadilah semacam cerita berbingkai. Cerita, tuturan dari para informan itulah yang diungkapkan oleh peneliti, dengan sendirinya dengan analisis seperlunya, bahkan dengan memasukkan metode dan teori tertentu. Dengan cara kerja yang sama seorang novelis, dengan kemampuan imajinasinya mengungkapkan kembali pengalamanpengalamannya, misalnya, dengan menampilkan ego alter dan berbagai bentuk mediator lain dalam rangka membangkitkan kembali memori masa lampaunya. Baik dalam penulisan etnografi maupun novel terjadi 'kerja sama' yang harmonis antara pemberi informasi dengan penulis informasi.

Dari sudut pandang yang berbeda maka pada dasarnya novel adalah etnografi itu sendiri, novel juga ditulis dengan didahului oleh penelitian, wawancara, bahkan juga mungkin menyebarkan semacam kuesioner. Beberapa novel modern juga disertai dengan catatan kaki, peta, dan foto, sehingga dari segi kualitas intelektualitas dan ilmu pengetahuan, seperti karya-karya Jules Verne, novel justru lebih bersifat ilmiah. Dengan singkat, tidak bisa dibedakan secara jelas antara kedua jenis karya tersebut. Ketelitian, kecermatan kedua penulis dalam melukiskan komplikasi tokoh dan peristiwa menambah kabur batas-batas di antaranya. Selama ini imajinasi yang dianggap sebagai ciri utama, dalam banyak hal juga mengandung kelemahan. Etnografer, dengan mekanisme pemplotan pada gilirannya juga menggunakan imajinasi termasuk kreativitas. Apakah Abangan, Santri, dan Priayi dalam Masyarakat Jawa benar-benar merupakan sebuah karya antropologi atau sebaliknya sebuah novel? Sebaliknya, Para Priayi (Umar Kayam), demikian juga Bumi Manusia (Pramoedya Ananta Toer), karya-karya terakhir Alisjahbana apakah karya sastra atau sebaliknya karya etnografi?

Akhirnya, hanya kulit luarlah yang mengantarkan kepada pembaca untuk mengetahui buku apa yang sedang dibaca. Dalam kover buku pada umumnya sudah terkandung berbagai tanda yang menunjukkan perbedaan antara karya ilmiah dengan karya sastra, bahkan di toko buku ditempatkan dalam rak buku yang berbeda. Tanda yang paling jelas pada umumnya tercantum di sudut kiri atau kanan dengan tulisan 'sebuah novel', 'sebuah karya etnografi', 'sebuah biografi atau otobiografi', 'sebuah kisah perjalanan', dan sebagainya. 


\subsection{Ciri-ciri Antropologi Sastra}

Sebagai mata rantai terakhir perkembangan antropologi dan antropologi budaya di satu pihak, psikologi sastra dan sosiologi sastra di pihak lain, antropologi sastra dianggap sebagai memiliki nilai tersendiri sehingga mutlak perlu didefinisikan, dikembangkan, dan dilembagakan.

1) Pertama, antropologi sastra berfungsi untuk melengkapi analisis ekstrinsik di samping sosiologi sastra dan psikologi sastra.

2) Kedua, antropologi sastra berfungsi untuk mengantisipasi, mewadahi kecenderungan-kecenderungan baru hasil-hasil karya sastra, di dalamnya banyak dikemukakan masalah-masalah kearifan lokal.

3) Ketiga, antropologi sastra jelas diperlukan dalam kaitannya dengan keberadaan bangsa Indonesia, di dalamnya terkandung beraneka ragam adat kebiasaan, seperti: mantra, pepatah, lelucon, motto, pantun, dan sebagainya, yang sebagian besar juga dikemukakan secara estetis, dalam bentuk sastra.

4) Keempat, antropologi sastra merupakan wadah yang sangat tepat bagi tradisi dan sastra lisan yang selama ini menjadi wilayah perbatasan disiplin antropologi dan sastra.

5) Kelima, antropologi sastra dengan sendirinya mengantisipasi kecenderungan kontemporer, yaitu perkembangan multidisiplin.

Seperti sosiologi sastra, kesulitan yang ditemukan dalam proses analisis adalah mempertemukan kedua disiplin ke dalam bentuk hubungan yang bermakna, menemukan konsep-konsep yang relatif sama dari dua bidang ilmu yang berbeda. Seperti diketahui, sebagai kelompok ilmu sosial humaniora hakikat antropologi adalah fakta empiris, sedangkan sastra, sebagai kelompok ilmu humaniora adalah kreativitas imajinatif. Terlepas dari perbedaan di atas, khususnya dalam kerangka multidisiplin, keduanya memiliki persamaan yang diduga akan memberikan hasil-hasil yang sangat bermanfaat. Benar, objek antropologi lebih nyata, lebih faktual, sebaliknya objek karya sastra lebih imajinatif, lebih kreatif, bahkan artifisial, tetapi perkembangan terakhir menunjukkan bahwa jarak kedua disiplin cenderung bertambah sempit, bahkan menjadi kabur. Fakta empiris sebagai ciri utama antropologi tidak bisa melepaskan diri dari kreativitas, bahkan imajinatif. Demikian juga sebaliknya karya sastra dalam rangka memperoleh pengakuan masyarakat maka karya harus dimasukkan ke dalam struktur sosial yang menghasilkannya. 
44| Mabasan - Vol. 5, No. 1, Januari-Juni 2011

Pada gilirannya karya sastra, termasuk karya-karya yang paling absurd pun berangkat dari fakta yang ada dalam masyarakat. Unsur-unsur kreasi dan imajinasinya dibangun melalui fakta tersebut. Kualitas karya sastra, karya seni pada umumnya tergantung dari 'bagaimana' cara menyajikannya, bukan 'apa' yang disajikan. Karya sastra yang dilepaskan sama sekali dari fakta tersebut sulit dipahami, mungkin lebih tepat dimasukkan sebagai semata-mata mimpi. Cinta, benci, iri hati, loba, angkuh, dermawan, dan berbagai bentuk sifat manusia yang pada umumnya dibedakan menjadi dua macam, yaitu baik dan buruk ada di mana-mana, sebagai hakikat universal. Tetapi, sebagai karya seni personifikasinya disesuaikan dengan lokasi di mana cerita terjadi. Nama-nama pelaku, bagaimana cerita berkembang, sebagai pemplotan disebut sebagai proses kreatif imajinatif.

Proses terakhir ini secara keseluruhan merupakan kompetensi pengarang, sebagai subjek kreator, di dalamnya terjadi komplikasi, tumpang tindih antara kenyataan dan rekaan, antara fakta dan fiksi. Meskipun demikian, sesuai dengan hakikatnya yang dominan dalam karya sastra adalah imajinasi. Oleh karena itulah, karya sastra tidak dapat digunakan sebagai tolok ukur suatu peristiwa tertentu. Karya sastra hanyalah refleksi, cermin, representasi menurut pemahaman teori sastra kontemporer. Oleh karena itu pulalah, karya sastra pada dasarnya tidak bisa diadili, dilarang penerbitannya, misalnya dengan tuduhan sebagai mewakili ideologi tertentu seperti karya-karya Paramoedya Ananta Toer. Tokoh-tokoh seperti Bima dan Arjuna, Jayaprana dan Layonsari, Sitti Nurbaya dan Datuk Maringgih, Drakula, Nyi Loro Kidul, dan sebagainya, dan dengan demikian Ontosoroh, hanyalah mewakili sifat-sifat manusia tertentu yang ada dalam masyarakat. Sifat-sifat yang dimaksudkan justru merupakan milik bersama yang secara kebetulan mungkin berbeda dengan sifat, situasi, dan kondisi pembacanya. Dengan singkat, sebagai kualitas estetis tujuan karya sastra, karya seni pada umumnya adalah keindahan itu sendiri, bukan fakta dan kenyataan-kenyataan lain yang ada dalam masyarakat.

Dalam teori kontemporer, khususnya dalam kaitannya dengan peranan pengarang, subjek kreator dalam pengertian yang lebih luas, perbedaan antara antropologi dengan karya sastra terletak dalam peran dan kedudukan manusia itu sendiri. Dalam antropologi khususnya antropologi fisik pusat perhatiannya jelas tercurah pada manusia itu sendiri, manusia merupakan segala-galanya, sehingga sulit dibedakan antara antropologi dengan dunia kedokteran, termasuk arkeologi. Dalam sastra fungsi dan kedudukan tersebut mengalami pasang surut. 
Dengan melihat perkembangan sejarah Barat, dominasi manusia dimulai sejak Abad Pertengahan (cf. Teeuw, 1988:155-169) hingga akhir abad ke-19, Abad Romantisisme. Tetapi abad ke-20 terjadi titik balik, pengarang disembunyikan, sebagai anonimitas, manusia justru dikenali melalui karyanya. Perbedaan seperti ini tidak mengurangi nilai dan makna antropologi sastra sebagai disiplin yang baru. Sebagai interdisiplin, antropologi sastra jelas memberikan dominasi terhadap hakikat karya sastra, sedangkan ciri-ciri antropologis menduduki posisi sekunder. Konsekuensi logis yang ditimbulkan, baik data maupun metode dan teorinya merupakan unsur-unsur yang disepakati dalam bidang sastra dan dengan demikian dianalisis dengan menggunakan metodologi sastra.

Analisis aspek ekstrinsik, khususnya antropologi sastra diperlukan untuk melengkapi pemahaman terhadap kompleksitas dan heterogenitas karya sastra di satu pihak, mengantisipasi perkembangan interdisiplin di pihak lain. Sebagai dunia yang otonom, sebagai mikrokosmos, kebebasan sekaligus kemampuan sastra adalah mengambil, menceritakan berbagai masalah kehidupan manusia yang ada dalam masyarakat. Oleh karena itu, sering disebut bahwa sastra memiliki sifat rakus, memasukkan berbagai masalah sehingga dapat dibicarakan dari berbagai segi. Kebebasan yang dimaksudkan jelas bukan tanpa batas, tetapi dilakukan melalui selektivitas yang tinggi, sehingga suatu karya memiliki nilai-nilai yang tinggi, memiliki kualitas estetis.

Seperti di atas, ciri-ciri keberhasilan karya diperoleh melalui dua aspek pokok, yaitu masalah yang diceritakan, dan yang lebih penting bagaimana cara menceritakannya. Dengan semata-mata melihat aspek pertama, sebagai cerita maka tidak ada perbedaan prinsip antara karya antropologi (baca etnografi) dengan sebuah cerpen atau novel. Demikian juga antara mantra dengan puisi dan bentuk-bentuk terikat yang lain. Berbagai peristiwa, seperti: ngaben (pembakaran mayat dalam agama Hindu Bali), khitan (pemotongan kulup dalam agama Islam), katoba dan kankilo (khitan di Sulawesi Tenggara) sekaten (upacara ritual dalam kesultanan Yogyakarta), dan sebagainya adalah aspekaspek kehidupan manusia tetapi disusun dan diceritakan secara literer. Sangat banyak masalah yang dapat diadopsi, dari yang tidak berarti menjadi berarti, dilukiskan, diplotkan secara stilistis, estetis, sehingga bernilai literer sekaligus antropologis. Meskipun demikian, apa pun bentuknya karya yang dihasilkan tidak bisa disebut sebagai karya antropologi, tetapi karya sastra. Dengan kalimat lain, hasil akhirnya adalah karya sastra yang bernilai literer tetapi memuat 
unsur-unsur antropologis. Manfaat yang dihasilkan tidak terbatas, sebab keindahan merupakan milik semua orang.

Mengingat perkembangan peradaban manusia secara keseluruhan di satu pihak, perkembangan interdisiplin seperti kajian budaya di pihak lain, dengan tidak mengabaikan nilai dan sumbangan yang telah diberikan oleh sosiologi sastra dan psikologi sastra, diduga bahwa antropologi sastra memiliki masa depan yang cukup cerah. Artinya, antropologi sastra akan banyak menarik minat khususnya di kalangan akademis. Sangat banyak tradisi, adat kebiasaan, kearifan lokal, dan berbagai bentuk kehidupan manusia yang belum bermakna sebab belum terungkapkan. Benar, sebagian sudah terungkap dalam berbagai disiplin, seperti sejarah, antropologi itu sendiri, dan berbagai ilmu pengetahuan lain, tetapi perlu diketahui bahwa karya sastra memiliki ciri-ciri yang sama sekali berbeda, yaitu cara-caranya yang tidak langsung, implisit, mengevokasi emosi melalui susunan bahasa (stilistika) dan susunan cerita (plot). Sesuai dengan hakikatnya, daya tarik lain yang justru merupakan ciri utamanya adalah aspek estetisnya.

Pada dasarnya semua karya, khususnya fiksi mengandung aspek-aspek sosiologis, psikologis, dan atropoplogis. Perbedaannya semata-mata terkandung dalam dominasinya. Seperti diketahui, sebuah karya hampir tidak pernah mencantumkan secara eksplisit kata-kata sosiologi, psikologi, dan dengan demikian antropologi. Dalam hubungan inilah diperlukan kepekaan seorang peneliti sehingga dapat menentukan sikap bahwa sebuah karya, suatu angkatan dapat disebutkan sebagai memiliki ciri-ciri dominan sebagai bahan analisis. Ciri-ciri yang dimaksudkan harus dicari. Oleh karena karya sastra adalah seni bahasa, maka petunjuk utama untuk memperolehnya adalah bahasa, misalnya, melalui sinonim, ekuivalensi, dan penafsiran bahasa itu sendiri secara keseluruhan, sebagai wacana. Sosiologi sastra dengan sendirinya berkaitan dengan masyarakat, intensitas rangkaian peristiwa dan kejadian. Goldmann (1970:584-585) menggunakan persamaan struktur, sebagai simetri dan homologi sebagai salah satu cara untuk menentukan hubungan antara karya sastra dengan masyarakat. Psikologi berkaitan dengan unsur-unsur kejiwaan, dalam hubungan ini tokoh dan penokohan.

Seperti di atas, antropologi sastra dengan sendirinya berkaitan dengan tradisi, adat istiadat, mitos, dan peristiwa-peristiwa kebudayaan pada umumnya, sebagai peristiwa yang khas yang pada umumnya berkaitan dengan peristiwaperistiwa masa lampau. Meskipun demikian, dalam perkembangan berikut, 
seperti dinyatakan melalui definisi kebudayaan secara luas, yaitu keseluruhan aktivitas manusia, maka ciri-ciri antropologis karya sastra dapat ditelusuri melalui keseluruhan aktivitas tersebut, baik yang terjadi pada masa yang sudah lewat maupun sekarang, bahkan juga pada masa yang akan datang. Koentjaraningrat (1974:82) menunjukkan tujuh ciri kebudayaan yang dapat digunakan untuk mengidentifikasi ciri-ciri antropologis, yaitu: a) peralatan dan perlengkapan kehidupan manusia, b) mata pencaharian dan sistem ekonomi, c) sistem kemasyarakatan, d) bahasa, baik lisan maupun tulisan, e) kesenian dengan berbagai mediumnya, seperti seni lukis, seni rupa, seni tari, seni drama, dan sebagainya, khususnya seni sastra, f) sistem pengetahuan, dan g) sistem religi. Ngaben, Nyepi, potong gigi, potong rambut, demikian juga bunyi kentongan, bunyi cecak dan tokek, mimpi, dan sebagainya dapat dianggap sebagai petunjuk dan dengan demikian sebagai memiliki persamaan dangan ciri-ciri antropologis tersebut.

Novel-novel yang ditulis sekitar tahun 1920-an yang juga dikenal dengan nama Angkatan Balai Pustaka, sarat dengan aspek-aspek antropologis. Hubungan dengan hikayat dan genre-genre sastra lama yang lain di satu pihak, adanya niat para penulis untuk mengemukakan berbagai peristiwa nyata yang ada dalam masyarakat di pihak lain, dianggap sebagai salah satu sebab utama kuatnya ciri-ciri antropologis karya sastra periode tersebut. Tema-tema kawin paksa, sistem kekerabatan dalam bentuk matrilineal, dan berbagai bentuk ritual religius yang berkaitan dengan komunitas masing-masing novel diharapkan akan memberikan ciri analisis yang berbeda, warna lain dibandingkan dengan analisis yang sudah banyak dikemukakan. Kegagalan dalam membentuk rumah tangga antara Hanafi dan Corrie (Salah Asuhan), di samping sebagai akibat tidak dipenuhinya tata bahasa kekeluargaan Minangkabau, juga dijelaskan dalam kaitannya dengan perbedaan ras, Barat dan Timur, nonpribumi dan pribumi. Dalam memutuskan pilihannya terhadap Hanafi, Corrie, sebagai bangsa Barat juga mempercayai bunyi tokek. Dengan singkat analisis antropologis dan analisis ekstrinsik sastra yang lain sekaligus memberikan kualitas objektif dan estetis. Oleh karena itu, sering dikatakan bahwa analisis pada dasarnya sama dengan mengungkapkan kembali isi suatu karya sastra dengan berbagai permasalahannya. 
48| Mabasan - Vol. 5, No. 1, Januari-Juni 2011

\subsection{Perkembangan Antropologi Sastra di Masa yang Akan Datang}

Sebagai disiplin baru di satu pihak analisis antropologi sastra cukup menarik, tetapi di pihak lain juga menimbulkan berbagai tantangan, kesulitan. Pertama, berbeda dengan sosiologi dan psikologi satra, objek antropologi sastra jelas terkandung dalam antropologi yang secara tidak langsung menyarankan orientasi ke masa lampau, di dalamnya terkandung mitos, tradisi, dan berbagai kebiasaan masyarakat lama. Mungkin berbagai ciri dengan berbagai bentuknya ada dan masih bertahan dalam masyarakat kontemporer, tetapi penelitian yang baik, mendalam, dan menyeluruh harus menelusuri ke aspek-aspek historisnya. Kedua, tradisi yang sudah punah dapat direkonstruksi melalui media tulisan, lukisan, dan foto, atau media teknologi komunikasi modern seperti televisi, film, dan bentuk-bentuk pementasan lain sehingga objek tersebut hadir dalam kontemporaritas peneliti. Dialektika antara tradisi yang sudah hilang dengan paradigma modern, bahkan postmodern justru menampilkan sesuatu yang berbeda dan menarik. Bagaimana cerita lisan Si Malin Kundang setelah diangkat ke dalam media televisi, sudah tentu dengan berbagai perubahan sesuai dengan kemampuan teknologi, atau sebaliknya bagaimana Sitti Nurbaya sebagai novel kontemporer, dengan kualitas imajinatif, tetapi kemudian tokoh-tokoh utamanya justru dibuatkan kuburan jelas merupakan masalah yang sangat menarik. Baik Si Malin Kundang maupun Sitti Nurbaya pada gilirannya menjadi lebih nyata dari kenyataan yang sesungguhnya, sebagai hiperealitas.

Sebagai disiplin yang baru antropologi sastra berutang pada berbagai penelitian terdahulu, khususnya yang secara serius mengangkat berbagai peristiwa kebudayaan yang terjadi pada masa lalu, sekaligus dengan mekanisme pementasannya, seperti: kentrung (Jawa Timur), kapu-kapuuna (Sulawesi Tenggara), pununange (Flores), masatua (Bali), guslar (Yugoslavia), shaman (Eskimo), jongleur (pembaca puisi-puisi istana abad ke-12). Sebagai tradisi lisan maka cara-cara penampilannya merupakan peristiwa yang sangat penting sebab dalam proses tersebutlah terkandung dinamikanya, struktur penceritaannya, serta nilai-nilai sastranya secara keseluruhan termasuk ciri-ciri antropologisnya. Sistem kekerabatan, sistem religi, dan berbagai bentuk hubungan lain, baik antara manusia dengan manusia, maupun antara manusia dengan alam semesta dan Tuhan, yang secara keseluruhan dinyatakan melalui penggunaan bahasanya, dalam hubungan ini bahasa lisan, dapat digunakan sebagai korpus dan data antropologi sastra. 
Dengan melihat berbagai persamaan antara antropologi dan sastra, maka tidak ada alasan lagi untuk menunda apalagi menolak kehadiran antropologi sastra. Seperti di atas, kedua disiplin sejak akhir abad ke-18 telah menjadi semacam dwitunggal, antara etnografi dan linguistik untuk memahami sukusuku bangsa yang berada di luar Eropa. Sikap yang diperlukan adalah menata kembali secara teoretis koseptual pola-pola hubungan yang sudah ada. Atas dasar penelitian-penelitian yang dilakukan oleh Levi-Strauss (Fokkema and Kunne-Ibsch, 1977:71-72), misalnya, ternyata bahwa ada hubungan yang signifikan, analog antara struktur karya sastra dengan struktur mitos. Masalah yang agak sulit dimengerti adalah kenyataan bahwa dalam mitos terkandung kualitas estetis sehingga pada taraf tertentu mitos tidak berbeda dengan karya seni. Oleh karena itu, tidak secara kebetulan Levi-Strauss dengan Jakobson, sebagai antropolog (baca etnolog) dan linguis melakukan penelitian mengenai "Les Chats" karangan Baudelaire. Dengan singkat, persamaan bukan masalah yang dicari-cari melainkan memang benar dan dengan demikian perlu dianalisis. Penelitian Roland Barthes $(S / Z, 1974)$ mengenai novel pendek Sarrasine (Balzac) dan penelitian-penelitian lain mengenai mitologi menunjukkan dengan jelas analisis antropologi sastra.

Hubungan bermakna antara antropologi dengan sastra seperti di atas juga dapat dilihat antara sejarah dengan sastra. Sastra sejarah dan novel sejarah adalah dua genre yang sudah lama dikenal dalam bidang sastra, di dalamnya unsur-unsur sejarah memegang peranan penting. Secara tradisional sejarah dan satra dianggap sebagai dua gejala yang bertentangan secara diametral. Hakikat sejarah adalah fakta sedangkan hakikat sastra adalah fiksi, imajinasi. Dalam teori-teori kontemporer perbedaan yang dimaksudkan makin diragukan, khususnya dengan melihat mekanisme penulisan sejarah yang semakin subjektif. Salah seorang tokoh yang sering disebut sebagai memiliki peranan penting dalam hubungan ini adalah Hayden White. Menurutnya (1987: 92) penyusunan sejarah tidak jauh berbeda dengan penyusunan sebuah karya sastra, mereka sama-sama menyeleksi, menyusun kembali dari keberagaman peristiwa dan tokoh ke dalam totalitas tertentu, semacam pemplotan. Pada gilirannya sejarah pun bukan penciptaan kembali masa lampau seperti dipahami dalam kehidupan sehari-hari, tetapi penciptaan suatu genre tertentu. 
50| Mabasan - Vol. 5, No. 1, Januari-Juni 2011

\section{Penutup}

Sebagai interdisiplin, maka hubungan antara satu ilmu dengan ilmu yang lain, seperti: linguistik kebudayaan, antropologi linguistik, sosiologi sastra, psikologi sastra, dan sastra sejarah, khususnya antropologi sastra diharapkan menampilkan dimensi-dimensi baru yang selama ini belum terungkap, baik sebagai akibat keterbatasan teori dan metode maupun belum adanya kepekaan terhadap hakikat objek. Masalah pertama dapat dipecahkan dengan menggunakan teori-teori yang sudah ada, sebagai teori formal, baik dengan cara mengaplikasikannya secara keseluruhan maupun memodifikasikannya sesuai dengan hakikat objek. Pada masalah yang kedualah terkandung manfaat sekaligus makna suatu penelitian multidisiplin sebab melaluinya dapat digali berbagai khazanah kebudayaan dalam rangka memperkaya sekaligus meningkatkan kualitas kehidupan manusia.

\section{Daftar Pustaka}

Bachtiar, Harsja W. 1981. "The Religion of Java: sebuah Komentar" (dalam Abangan, Santri, Priayi dalam Masyarakat Jawa, Clifford Geertz, ed., Jakarta: Pustaka Jaya, hlm. 521—551).

Barthes, Roland. 1974. S/Z. New York: Hill and Wang.

Fokkema, D.W. and Elrud Kunne-Ibsch. 1998. Theories of Literature in the Twentieth Century: Structuralism Marxism Aesthetics of Reception Semiotics. London: C. Hurst \& Company.

Geertz, Clifford. 1973. The Interpretation of Cultures: Selected Essays. New Jersey: Princeton University Press.

Goldmann. 1970. "The Sociology of Literature: Status and Problems of Method" (dalam The Sociology of Art and Literature: a Reader, Milton C. Albrecht, dkk., eds., New York and Washington: Praeger Publications, hlm. 582-609).

Koentjaraningrat. 1974. Pengantar Antropologi. Jakarta: Aksara Baru.

Teeuw, A. 1988. Sastra dan Ilmu Sastra: Pengantar Teori Sastra. Jakarta: Pustaka Jaya.

White, Hayden. 1987. Tropic of Discourse: Essays in Cultural Criticism. Baltimore and London: The John Hopkins University Press. 